\section{Commentary: Decision-making for right ventricle to pulmonary artery conduit selection: Statistical models and clinical practice}

\author{
Nicholas D. Andersen, MD, and \\ Joseph W. Turek, MD, PhD
}

The ideal right ventricle to pulmonary artery (RVPA) conduit in children is readily available, appropriately sized for patient anatomy, accommodating of somatic growth, accommodating of future transcatheter interventions, and resistant to structural deterioration and endocarditis. In contemporary practice, the surgeon can essentially make 2 choices: which type of conduit to place and what size. Although this seems to impart some degree of autonomous decision-making by the surgeon, in real-world practice there is often much less flexibility due to limitations of patient anatomy and conduit availability.

In the current issue of the Journal, Willetts and colleagues, ${ }^{1}$ from Birmingham, United Kingdom, provide an exemplary and exhaustive review of RVPA conduit performance over a 30 -year period at their center in patients ranging from newborns to young adults. The 4 "traditional" conduit types that were compared included the aortic homograft, pulmonary homograft, composite porcine valve (Hancock, Medtronic, Minneapolis, Minn), and bovine jugular vein (Contegra, Medtronic). Patients were stratified into 3 groups effectively representing neonates $(0-5 \mathrm{~kg})$, infants and children $(5-20 \mathrm{~kg})$, and adolescents/young adults $(>20 \mathrm{~kg})$.

Overall, results were similar to prior reports and provide helpful guidance for conduit selection. Key conclusions were that lower patient weight was a significant risk factor for conduit failure, homograft options were superior to xenograft options in patients weighing $5-20 \mathrm{~kg}$, aortic and pulmonary homografts performed similarly, Contegra

From the Duke Children's Pediatric \& Congenital Heart Center, Duke Children's Hospital, Durham, NC.

Disclosures: The authors reported no conflicts of interest.

The Journal policy requires editors and reviewers to disclose conflicts of interest and to decline handling or reviewing manuscripts for which they may have a conflict of interest. The editors and reviewers of this article have no conflicts of interest.

Received for publication Jan 7, 2021; revisions received Jan 7, 2021; accepted for publication Jan 8, 2021; available ahead of print Jan 19, 2021

Address for reprints: Nicholas D. Andersen, MD, Division of Cardiovascular and Thoracic Surgery, Duke University Medical Center, 2301 Erwin Rd, DUMC 3443, Durham, NC 27710 (E-mail: Nicholas.Andersen@Duke.edu).

J Thorac Cardiovasc Surg 2021;162:1334-5

$0022-5223 / \$ 36.00$

Copyright (c) 2021 by The American Association for Thoracic Surgery

https://doi.org/10.1016/j.jtcvs.2021.01.018

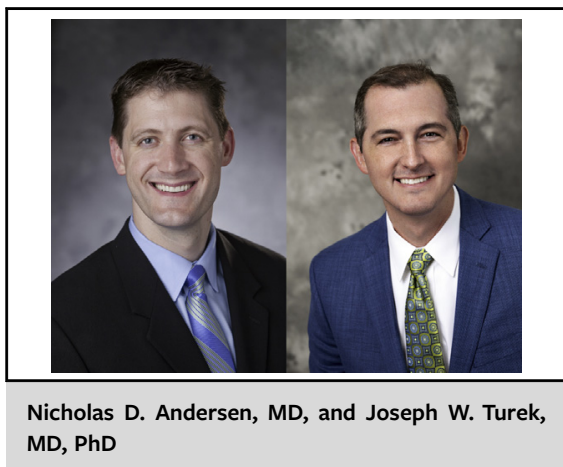

CENTRAL MESSAGE

RVPA conduit selection may in-

fluence durability in certain pa-

tient groups, but choices are

often limited by patient anatomy

and conduit availability.

grafts had a 4-fold higher rate of endocarditis, and statistical modeling suggested the best durability occurred in all patient groups when conduits were oversized to a Z-score of +3 or greater.

How should these findings be incorporated into clinical practice? In neonates, the availability of an appropriately sized conduit is often the largest obstacle. Homografts may not be available in small sizes, necessitating the use of xenograft alternatives. Although oversizing to a Z-score of +3 may be possible, other studies have found that oversizing conduits in the setting of truncus arteriosus is associated with increased mortality and adverse events, possibly as a result of a larger ventriculotomy, space limitations within the chest, or conduit compression/distortion. ${ }^{2}$ The present study only assessed conduit durability and excluded patients who did not survive 90 days, and therefore the more important relationship between conduit size and survival in neonates was not examined. Thus, conclusions regarding conduit size in neonates should be viewed with caution because there may be a competing or inverse relationship between conduit durability and survival in this fragile age group.

In small children $(5-20 \mathrm{~kg})$, the key recommendation appears to be to select a homograft option with a Z-score of +3 or greater. However, it is important to note that in the authors' practices, only $4.5 \%$ of patients (20/449) in this age group received RVPA conduits of this size. Further, a closer look at the data shows that the hazard ratios for conduits between a $Z$-score of +1 and +3 are similar. Thus, although oversizing to a $Z$-score of +3 appears important in the statistical models, real-world physician behavior 
demonstrated that in most patients a Z-score of +3 was not achieved, likely because of the perceived space constraints within the chest or a prohibitive mismatch between an oversized conduit and the size of the pulmonary artery confluence or right ventricular opening, leading the surgeon to select a smaller conduit option. It is also possible that the largest conduits were placed in patients with generously sized branch pulmonary arteries, which further led to the superiority of the results.

In the adolescent/young adult patient group ( $>20 \mathrm{~kg})$ in whom future somatic growth is perhaps less important, conclusions regarding conduit size become even more nebulous. No patients received conduits with a Z-score of more than +2 , and therefore conclusions regarding the performance of conduits with a $\mathrm{Z}$-score of +3 or greater seem even more theoretical and detached from clinical practice.

In summary, the article by Willetts and colleagues ${ }^{1}$ provides an exceptional glimpse into the past of practice patterns and durability of RVPA conduits in children and young adults over a 30-year period. However, in realworld practice there are often few options available to the surgeon for a given patient. Future advances in RVPA conduit technology will hopefully improve conduit performance and lead to additional alternatives. 3,4

\section{References}

1. Willetts RG, Stickley J, Drury NE, Mehta C, Stumper O, Khan NE, et al. Four righ ventricle to pulmonary artery conduit types. J Thorac Cardiovasc Surg. 2021;162: 1324-33.e3.

2. Mastropietro CW, Amula V, Sassalos P, Buckley JR, Smerling AJ, Iliopoulos I, et al. Characteristics and operative outcomes for children undergoing repair of truncus arteriosus: a contemporary multicenter analysis. J Thorac Cardiovasc Surg. 2019;157:2386-98.e4.

3. Boethig D, Horke A, Hazekamp M, Meyns B, Rega F, Van Puyvelde J, et al. A European study on decellularized homografts for pulmonary valve replacement: initial results from the prospective ESPOIR Trial and ESPOIR Registry data Eur J Cardiothorac Surg. 2019;56:503-9.

4. Miyazaki T, Yamagishi M, Maeda Y, Taniguchi S, Fujita S, Hongu H, et al. Longterm outcomes of expanded polytetrafluoroethylene conduits with bulging sinuses and a fan-shaped valve in right ventricular outflow tract reconstruction. J Thorac Cardiovasc Surg. 2018;155:2567-76.

\section{See Article page 1324.}

\section{Commentary: The conduit's gambit}

\section{Jonathan M. Chen, MD}

Historically, the preference of conduit type to establish right ventricle-to-pulmonary artery continuity has been largely a discussion of religion. Homograft artery with valve, porcine, or bovine jugular vein composite tubes, polytetrafluoroethylene with or without leaflets, and stem cell-seeded scaffolds all have been proposed as superior vehicles, where success is measured in years of durability and valve competence. Although the platonic flame burns brightly for a "living" connection that might

\footnotetext{
From the Cardiothoracic Surgery, Children's Hospital of Philadelphia, Philadelphia, $\mathrm{Pa}$.

Disclosures: The author reported no conflicts of interest.

The Journal policy requires editors and reviewers to disclose conflicts of interest and to decline handling or reviewing manuscripts for which they may have a conflict of interest. The editors and reviewers of this article have no conflicts of interest.

Received for publication Jan 13, 2021; revisions received Jan 13, 2021; accepted for publication Jan 13, 2021; available ahead of print Jan 19, 2021.

Address for reprints: Jonathan M. Chen, MD, Cardiothoracic Surgery, Children's Hospital of Philadelphia, 3401 Civic Center Boulevard-Suite 8574, Philadelphia,

PA 19104 (E-mail: chenj14@email.chop.edu).

J Thorac Cardiovasc Surg 2021;162:1335-6

0022-5223/\$36.00

Copyright (C) 2021 by The American Association for Thoracic Surgery

https://doi.org/10.1016/j.jtcvs.2021.01.049
}

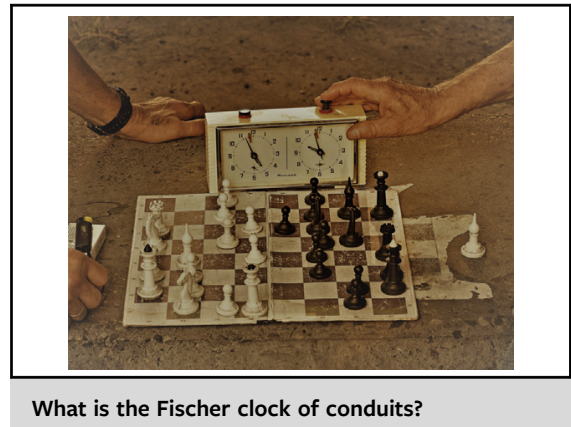

What is the Fischer clock of conduits?

CENTRAL MESSAGE

While "judicious oversizing" of

conduits hopes to maximize

durability, should we focus on

strategies of care that incorpo-

rate the chance of accelerated

deterioration or future trans-

catheter solutions?

enlarge to accommodate somatic growth while maintaining valve function, the reality is that currently most often the strongest influence for conduit selection is local availability. 